Таким образом, в студенческие годы закладывается основа таких личностных качеств, которая поможет молодому человеку успешно социализироваться в окружающем мире и стать масштабной личностью.

На сложном этапе жизни - обучении, дружба играет важную роль. Когда рядом есть верный друг - человек, готовый прийти на помощь, поддержать и мотивировать, появляется стремление идти вперед, преодолевая все трудности. Развивая различные стороны своей жизни, личность совершает мотивированные действия, которые невозможны без межличностного взаимодействия. На пути к успешной коммуникации существует много камней преткновения, преодолев которые, можно добиться результата.

$$
* * *
$$

1. Белянская Т.Э. Социально-психологические характеристики студенческого возраста // Ученые записки. Электронный научный журнал Курского государственного университета. 2020. № 3 (55). [Электронный pecypc]. — URL: https://api-mag.kursksu.ru/api/v1/get_pdf/3725.

2. Буева Л.П. Человек: деятельность и общение / Л.П. Буева. - Москва: Мысль, 1978. - 216 с.

3. Столяренко Л.Д., Самыгин С.И. Психология общения / Л.Д. Столяренко, С.И. Самыгин: учебник. 4-е изд. Ростов на Дону: Феникс, 2019. - 317 с.

4. Обухова Л. Ф. Возрастная психология. Учебник. Изд. 4. - М.: Педагогическое общество России, 2004. - 442 c.

5. Справочник практического психолога. Психодиагностика / С74 под общ. ред. С. Т. Посоховой. - М.: АСТ; СПб.: Сова, 2006. -671 с.

6. Немов Р.С. Общая психология: Краткий курс / Р.С. Немов. - Санкт-Петербург: Питер, 2007. - 304 с.

\title{
Кадыржанова Ж.Е. \\ Эмпирическое исследование экзистенциального кризиса зрелого возраста мужчин и женщин
}

Западно-Казахстанский инноваџионно-технологический университет doi: 10.18411/trnio-12-2021-134

(Казахстан, Уральск)

\section{Аннотация}

В статье рассмотрены гендерные различия в преодолении экзистенциального кризиса взрослого периода. Излагаются пути преодоления экзистенциального кризиса у мужчин и женщин. Особенности психофизиологического и психического здоровья у мужчин и женщин в период экзистенциального кризиса отражены по результатам эмпирических исследований.

Ключевые слова: гендерный характер, экзистенциальный кризис, жизненные позиции, жизнестойкость, ритм жизни.

\section{Abstract}

The article considers gender differences in overcoming the existential crisis of the adult period. The article describes ways to overcome the existential crisis in men and women. Features of psychophysiological and mental health in men and women during the existential crisis are reflected in the results of empirical studies.

Keywords: gender, existential crisis, resilience.

В настоящее время особое место в системе психологического знания занимает экзистенциально-гуманистическая парадигма, в контексте которой жизненный путь личности представляет собой индивидуальную систему решения экзистенциальных проблем, среди которых наиболее важной является отношение к собственной жизни. Нами было проведено исследование, цель которого заключалась в выявлении способов преодоления кризиса личности в различных критических ситуациях. В критических ситуациях личность сталкивается с необходимостью пересмотрению своих представлений о жизни и ее смысле, ценностях. Они представляют собой систему, основными компонентами которой являются 
следующие: степень принятия жизни и ее изменчивости, смерти и чувств по отношению к ней, себя и ответственности, чувство онтологической защищенности, видение смысла в жизни. [3, 84c]

В результате исследования терминальных ценностей по методике «Ценностные ориентации» М.Рокича, мы выяснили, что из представленных восемнадцати ценностей испытуемые считают приоритетными: здоровье, счастливая семейная жизнь, материально обеспеченная жизнь, уверенность в себе, интересная работа, любовь. Это объясняется тем, что в зрелом возрасте вышеперечисленные ценности становятся приоритетными. Так как, именно, в этом возрасте происходит переоценка смысла жизни, ее смысловая часть. И на первое место выходят семья и забота о ней. Такие ценности как развлечения, красота природы и искусства, счастье других, творчество, развлечения, общественное признание, познание занимают в иерархии ценностей последние места [1,38c]. Проведенное исследование показало, что принятие собственной жизни тесно связано с принятием себя, а также является важным компонентом в концепции жизни, позволяющим человеку видеть смысл жизни, относится к ней как к ценности, а также стремиться к собственному развитию и росту. Следует отметить, что приоритетными ценностями, как для мужчин, так и для женщин, в данном исследовании важными являются одни и те же ценности: здоровье, счастливая семейная жизнь, интересная работа, наличие друзей, любовь, материально обеспеченная и активная деятельная жизнь, жизнерадостность, образованность, ответственность и честность. Таким образом, гендерные различия не так уж велики, как принято считать. Так если женщины больше выражают чувства направленные на окружающих (проявление интереса к чувствам других, их потребностям, желаниям), то мужчины же наоборот проявляют больше эгоцентрических чувств (потребностей, желаний, собственных интересов). Из вышеуказанного можно сделать вывод, что эмоции и чувства у мужчин и женщин одинаковы, но в связи с их тендерными ролями они выражают их поразному $[5,41 \mathrm{c}]$. Именно в зрелом возрасте, человек воспринимает действительность сквозь призму либо прошлого опыта, либо своих представлений относительно будущего, либо его поведение становится респондентным (ситуативным). Поведение становится ситуативным, в связи с тем, что человек в зрелом возрасте, накопив значительный опыт, попадает в ситуацию необходимости переосмысления своих прежних жизненных позиций, достижений, ценностей, планов. Но, как правило, замечено, что мужчины и женщины, переживающие кризис зрелого возраста не извлекают смысл жизни из ситуации, а наделяют ее отдельными смыслами-значениями, находящимися в жестко локализованных временных регионах субъективного смыслового поля. В данном исследование было выявлено, что мужчины и женщины (в среднем 51,5\% от общей выборки) свою жизнь в целом воспринимают дискретно, ситуативно. Их личностные смыслы лишены направленности и временной перспективы, характеризуются низкими показателями внутренней свободы, низкой осмысленностью жизни, напряженностью. Только небольшой процент 18,2\% в среднем от общей выборки воспринимают жизнь как интересную, эмоционально насыщенную. В результате они характеризуются высокой осмысленностью, направленностью в жизни, гибкостью поведения и межличностной чувствительностью. [2, 28c].

Для того чтобы понять сходства и различия в преодолении трудностей мужчинами и женщинами, мы обратились к данным копинг-теста. В целом совладание со стрессом имеет у мужчин и женщин общие закономерности, возможно, обусловленные культурно и социально и проявляющиеся в частом использовании копинг-стратегий когнитивной сферы, что говорит о тенденции рационально перерабатывать сложившуюся ситуацию. Интересно, что женщины в большей степени, чем мужчины используют такие стратегии, как «планирования решения проблемы» и «самоактуализации». В поведении же мужчин чаще встречаются стратегии поиск решения проблем, принятие ответственности; бегство или уход из психотравмирующей ситуации - «бегство - избегание». Результаты исследования свидетельствуют о том, что мужчины и женщины зрелого возраста испытывают наибольшие затруднения в использовании эффективных копинг-стратегий эмоциональной сферы. 
Мужчины и женщины достаточно активны в преодолении жизненных трудностей, хотя не вполне удовлетворены успешностью этого преодоления. Женщины более эмоционально реагируют на кризисные ситуации и субъективно выше оценивают силу своих переживаний, чаще прибегают к внешней помощи для их разрешения и дольше воспринимают ситуации как окончательно неразрешенные, «хронические». Мужчины, наоборот, в кризисе пытаются контролировать свои эмоции, опираться в разрешении проблемы на собственные ресурсы и более решительно справляться с возникшими трудностями, не оставляя их на будущее. Примечателен тот факт, что женщины несколько в большей степени оценивают и наличие в переживаемых ими кризисных ситуациях экзистенциальных проблем смерти, смысла и одиночества. Мужчины рассматривают происходящие с ними ситуации в большей степени как столкновение с проблемой ответственности. Такие данные еще раз подтверждают идею о наличии гендерных аспектов в преодолении кризисов $[7,36 \mathrm{c}]$ Анализ данных выявил, что мужчины имеют высокий процент вовлеченности в жизненный процесс. Они более активны и уверенны в своих силах, способны самостоятельно справляться с трудными ситуациями в жизни, продолжая, при этом, эффективно работать, не теряя душевного равновесия. У них развит компонент контроля в ситуации стресса, который помогает бороться, находить новые пути решения проблем. Они рассматривают жизнь как способ приобретения и готовы действовать в отсутствие надежных гарантий успеха, на свой страх и риск. Женщины также активны и деятельны, но перед лицом стресса они теряют самообладание, становятся пассивными в преодолении трудностей. Следовательно, женщины чаще пассуют в трудных ситуациях в жизни. Развитие защитных механизмов имеет целью защиту личности от тревоги. Взаимоотношения между личностью и защитными механизмами носят внутренний и взаимный характер: механизмы защищают личность, а структура личности определяет какие именно механизмы будут использованы для защиты. Каждый индивид пользуется различными механизмами в разной степени, развивая свою самостоятельную систему защиты самоуважения. Таким образом, у женщин преобладает, следующий блок защит: «реактивное образование», «отрицание», «компенсация». Действие этого блока МПЗ осуществляется чаще всего на макросоциальном уровне. В данном блоке ключевая защита реактивное образование, которая меняет знак аффекта (например, агрессию на чрезмерный контроль над поведением близкого окружения - мужа или детей). У мужчин же проявляется интеллектуализация в качестве способа отстранения от аффекта с помощью выдвижения псевдоразумного оправдания со ссылкой на внешние обстоятельства [8,69c]. Такой защитный стиль позволяет оправдать и рационально объяснить собственное дезадаптивное поведение, неблаговидные поступки (обидчивость, раздражительность, агрессивность).

На различных этапах жизненного пути человек сталкивается с кризисными ситуациями, которые могут спровоцировать личностный (экзистенциальный) кризис. В разрешении кризисной ситуации можно выделить два основных выхода. Один состоит в том, что человек рискует, открываясь новым возможностям и преодолевая страх изменений. В этом случае человек переходит на следующую ступень своего развития, получает новый опыт, новые знания о мире и о себе [4, 104c]. Другой выход заключается в сохранении существующего порядка. Поэтому часто, выбирая потребность в безопасности и стремление к сохранению существующего порядка, человек приостанавливается в своем развитии, при этом ограничивая или даже разрушая себя.

Следовательно, что ситуация переживается как кризисная тогда, когда человек перестает видеть возможные выходы, но в тоже время в период кризиса клиент открыт новому для нового опыта, а это значит, что кризис может служить основанием для положительных перемен и стать важным личным опытом. Самая важная задача в работе с людьми, переживающими подобный кризис, - создать благоприятную, доверительную атмосферу и рассказать им о процессе, через который им предстоит пройти. На основании полученных результатов нами была составлена программа коррекционной работы. 
Как показало проведенное исследование, кризис представляет собой особое явление в структуре жизненного пути личности, в котором достаточно драматично присутствуют и активно проявляют себя две противоположные тенденции - тенденция к разрушению старого, отжившего, мешающего дальнейшему плодотворному проявлению личности, и тенденция к созданию нового, целостного, гармоничного, позволяющего личности подняться на новую ступеньку жизненного восприятия, понимания, осмысления. [3, 114c]

Рассмотренный нами кризис оказался двойне сложным, т.к. объединил в себе определенное наложение нескольких кризисных тенденций. Таким образом, нами были подтверждены и дополнены поставленные гипотезы исследования.

1. Кризис середины жизни (40-44 года) является неизбежным периодом жизненного пути личности. На данном этапе наблюдается возрастание личностных проблем, образующих кризис личности.

2. Ядром личностного кризиса середины жизни являются экзистенциальные проблемы, т.е. проблемы переосмысления пройденного жизненного пути, прежних ценностей, приоритетов, ориентиров, самоосознания и т.д. Экзистенциальный кризис в середине жизни является допустимой, но не неизбежной составляющей психического пространства человека.

3. Экзистенциальный кризис середины жизни обладает общими с кризисом начала зрелости и своими специфическими особенностями. К общим с кризисом начала зрелости особенностям относятся: отсутствие чувства счастья, чувства отчуждения с друзьями и потеря смысла жизни. К специфическим особенностям кризиса периода «середины жизни» относятся: неудовлетворенность жизненной самореализацией; потеря смысла жизни, ощущение безысходности, страх смерти, горечь от жизненных потерь и утрата самоуважения. Наличие психологического своеобразия в содержательном наполнении экзистенциального кризиса заставляет дифференцировать содержание практической помощи лицам, переживающим экзистенциальный кризис.

4. Выделены следующие психологические особенности лиц, переживающих экзистенциальный кризис середины жизни:

a) изменение ценностно-смысловой сферы;

б) дефекты Я-концепции;

в) отказ от несения ответственности за свою жизнь.[6, 44c]

Выявленные особенности личности в период переживания ею экзистенциального кризиса середины жизни обозначают направления работы в плане оказания психологической поддержки в личностном развитии таким лицам. Проведенное исследование не исчерпывает проблемы личностного развития в ситуации экзистенциального кризиса середины жизни и может быть продолжено в последующих исследованиях.

$$
* * *
$$

1. Ливехуд Б. Кризисы жизни-шансы жизни: Развитие человека между детством и старостью - Калуга Духов. Познание, 2014-38c.

2. Лэнгле А. "Что движет человеком?" Экзистенциально-аналитическая теория эмоций. - М.: Генезис, 2006.$28 \mathrm{c}$.

3. Поливанова К.Н. Психология возрастных кризисов.-М.:«Академия», 2000. - 84c.,114c.

4. Экзистенциальная психология. Под ред. Мэя Р.М.-Эксмо-Пресс, 2001.-104c.

5. Бабурин СВ., Баканова А.А, Психологическая помощь в острых кризисных ситуациях. СПб., 1999.-41с.

6. Овчинникова Ю.Г. О путях разрешения кризиса личностной идентичности// Вестник МГУ. Серия 14. Психология. - 2003. - №4. С.44c.

7. Олпорт Г. Становление личности. - М.: Смысл, 2002.-36c., 78c.

8. Шихи. Г. Возрастные кризисы - ступени личностного роста. СПб.: Ювента, 1999.-69с. 